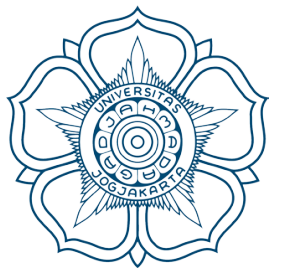

Judul Naskah

: HAK ULAYAT MASYARAKAT HUKUM ADAT DAN HAK MENGUASAI NEGARA DI TAMAN NASIONAL RAWA AOPA WATUMOHAI

Nama Penulis : Sahrina Safiuddin

MIMBAR HUKUM

$\begin{array}{ll}\text { DOI } & : \text { http://doi.org/10.22146/jmh.16681 } \\ \text { Penerbit } & : \text { Fakultas Hukum Universitas Gadjah Mada } \\ \text { URL } & : \text { jurnal.ugm.ac.id/jmh } \\ \text { E Issn } & : 2443-0994 \\ \text { P Issn } & : 0852-100 x\end{array}$




\title{
HAK ULAYAT MASYARAKAT HUKUM ADAT DAN HAK MENGUASAI NEGARA DI TAMAN NASIONAL RAWA AOPA WATUMOHAI*
}

\author{
Sahrina Safiuddin** \\ Hukum Lingkungan Fakultas Hukum Universitas Halu Oleo, \\ Kampus Hijau Bumi Tridharma Jl. H.E.A Mokodompit No. 1 Anduonohu, Kendari, Sulawesi Tenggara, \\ 93232
}

\begin{abstract}
Communal right cannot implemented even legality of that was recognized. This research want to know the concept and implentation of arrangement about relationship of communal right and the right of controlling of the state in Rawa Aopa Watumohai National Park. This research is an empirical law. The results are Firstly, concepts regulation of relations communal rights of indigenous people and to the right control of the state contained in Article 33 paragraph (3) NRI 1945 Constitution. Secondly, to implementing the right still have to wait stipulation from the National Parks in this case related to the central government as the implementing authority.
\end{abstract}

Keywords: communal right, national park, right control of the state.

\section{Intisari}

Hak ulayat tidak selalu dapat diimplementasikan meskipun memiliki dasar pengakuan hukum. Penelitian ini untuk mengetahui konsep pengaturan dan implementasi dari hubungan antara hak ulayat dengan hak menguasai Negara di Taman Nasional Rawa Aopa Watunohai. Penelitian ini penelitian hukum empiris. Hasil penelitian adalah pertama, konsep pengaturan hak ulayat dan hak menguasai negara diatur Pasal 33 ayat (3) UUD NRI 1945. Kedua, implementasi hak ulayat ditentukan pihak Taman Nasional terkait dengan pemerintah pusat sebagai pelaksana wewenang/kekuasaan dari negara.

Kata Kunci: hak menguasai negara, hak ulayat, taman nasional.

\section{Pokok Muatan}

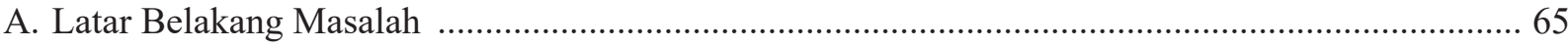

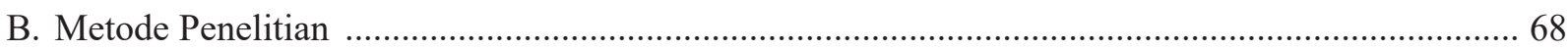

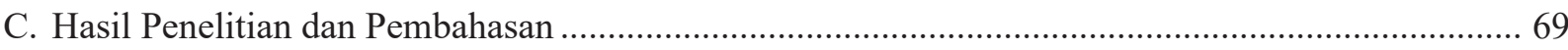

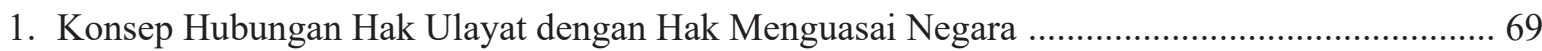

2. Implementasi Hubungan Hak Ulayat dengan Hak Menguasai Negara di Taman Nasional Rawa

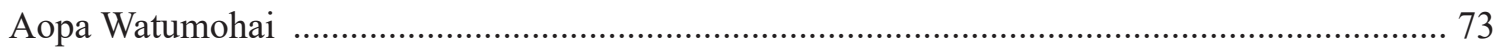

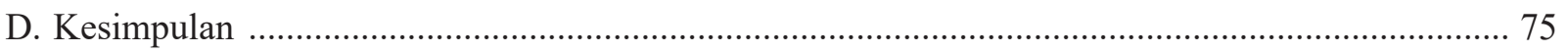

Hasil Penelitian Mandiri, 2016

** Alamat Korespendensi: $\underline{\text { sahrina.lir@gmail.com. }}$ 


\section{A. Latar Belakang Masalah}

Hukum tidak lepas dari kehidupan manusia sehingga pembicaraan mengenai hukum tidak dapat lepas dari pembicaraan tentang kehidupan manusia. Manusia hidup berkelompok sebagai kesatuan masyarakat dan masyarakat tersebut lahir dan berkembang dengan budaya dan nilai-nilai hukum yang juga beragam. Keberagaman ini umumnya disebut juga dengan pluralitas, yang secara alamiah juga berlaku dengan perangkat nilai-nilai yang diyakini oleh masyarakat tersebut.

Kehidupan masyarakat terus berkembang mulai dari masyarakat kelompok kecil, suku, bangsa dan negara termasuk kemudian masyarakat internasional yang aturan-aturannya tidak bisa dihindari oleh setiap orang. Kehadiran negara semakin menguatkan adanya keberagaman hukum karena negara dengan kewenangannya dalam mengatur kehidupan bernegara juga turut membentuk hukum. Hukum inilah yang lazim disebut dengan hukum negara.

Pada waktu yang bersamaan dalam suatu kelompok kehidupan masyarakat juga berlaku sistem hukum selain hukum Negara yakni hukum adat yaitu hukum yang dibangun melalui tradisi, umunya berbentuk tidak tertulis atau juga termasuk dalam hal ini adalah hukum agama sampai dengan hukum negara. Hal ini secara bersama-sama berlaku berbagai sistem hukum yang berbeda dikenal sebagai keberagaman hukum atau pluralisme hukum. Menurut J. Griffth:

Pluralisme hukum dalam konsepnya dapat dibagi dalam strong legal pluralism dan weak legal pluralism. Suatu kondisi dikatakan strong legal pluralism jika masing-masing sistem hukum yang beragam itu otonom dan eksistensinya tidak bergantung kepada hukum negara, jika keberadaan salah satu sistem hukum tergantung kepada pengakuan dari hukum negara maka kondisi seperti itu disebut dengan weak legal pluralism. ${ }^{1}$
Secara teori, Maria S. W. Soemardjono dengan mengutip Becker, menyatakan bahwa: ${ }^{2}$

Legal pluralism dapat dimaknai dalam arti sempit dan arti luas. Dalam arti sempit, pemaknaannya didasarkan pada dual system theory yakni ditandai dengan bergabungnya sistem hukum barat dengan sistem hukum adat. Dalam hal ini terdapat 2 (dua) sistem hukum yang masing-masing sifatnya otonom, hidup berdampingan dan berinteraksi dalam peristiwa-peristiwa tertentu. Dalam arti sempit ini ditandai juga dengan terdapatnya dominasi hukum negara terhadap hukum adat (state law pluralism). Dalam arti luas legal pluralism menunjuk pada situasi nyata yaitu terdapatnya berbagai sistem hukum yang ditaati dan keberadaannya tidak tergantung pada hukum negara. Khusus dalam konteks Indonesia bahwa pengakuan dan pengadopsian hukum adat tidak hanya melalui peraturan perundang-undangan tetapi juga yurisprudensi maka tampaknya Indonesia cenderung pada weak legal pluralism atau state law pluralism.

Persoalan hukum muncul ketika negara ingin membangun suatu sistem hukum yang berlaku secara nasional untuk seluruh wilayah di tengah masyarakat yang telah mempunyai hukum beranekaragam. Menurut penganut aliran sosiological jurisprudence seperti Eugen Ehlirch, bahwa hukum yang baik dan efektif adalah hukum yang sesuai dengan atau mencerminkan nilai-nilai yang hidup dalam masyarakat (living law). ${ }^{3}$ Konteks Indonesia, penerapan prinsip keanekaragaman dalam kesatuan hukum khususnya dalam bidang sumber daya alam perlu mendapat perhatian karena terhadap bidang sumber daya alam kerap bersinggungan secara langsung antara hukum negara dengan hukum adat masyarakat. Bagi masyarakat hukum adat hubungan dengan sumber daya alam lebih dari sekedar hubungan produksi (ekonomi) namun memiliki hubungan magis religius sebagai

J. Griffth, 1986, "What is Legal Pluralism?”, Journal Of Legal Pluralism, No. 24, hlm. 1-55.

Maria S.W. Soemardjono, "Pluralisme Hukum Di Bidang Pertanahan", Makalah, Konferensi Internasional tentang Penguasaan Tanah dan Kekayaan Alam di Indonesia yang Sedang Berubah: Mempertanyakan Kembali Berbagai Jawaban, Yayasan Kemala, Jakarta, 11-13 Oktober 2004.

Mochtar Kusumaatmadja, 1976, Hukum, Masyarakat dan Pembinaan Hukum Nasional: Suatu uraian tentang Landasan Pikiran, Pola dan Makanisme Pembaharuan Hukum di Indonesia, Binacipta, Bandung, hlm. 14. 
salah satu corak dari hukum adat. ${ }^{4}$

Menurut perspektif pluralisme hukum antara hukum negara dan hukum adat masing-masing berdiri sendiri namun berlaku secara bersamaan. Hukum negara, diartikan sebagai aturan hukum yang dilahirkan oleh negara menurut kewenangannya membuat aturan baik baik di tingkat pusat maupun tingkat daerah. Hukum negara dalam hal ini dapat berupa konstitusi dan peraturan perundangundangan, produk hukum yang dikeluarkan oleh eksekutif baik pusat maupun daerah berdasarkan Peraturan Menteri Dalam Negeri tentang prosedur penyusunan produk hukum daerah termasuk dalam pengertian hukum negara yang dimaksud. Eksistensi dari hukum negara ini diantaranya adalah melalui implementasi hak menguasai negara.

Jenis hukum di Indonesia selain hukum negara juga terdapat hukum adat. Hukum adat yang dimaksud adalah aturan hukum atau ketentuanketentuan yang ditaati oleh masyarakat karena lahir dan berkembangnya seiring dengan perkembangan masyarakat tersebut, yang bukan merupakan produk lembaga negara, sebagian besar tidak tertulis. Hukum adat adalah hukum yang tidak bersumber kepada peraturan. ${ }^{5}$ Konteks hukum adat sebagai sumber utama pembangunan hukum nasional, Seminar Hukum Adat dan Pembangunan Nasional oleh Lembaga Pembinaan Hukum Nasional Departemen Kehakiman di Yogyakarta pada tahun 1975, telah memberikan rumusan terhadap hukum adat yaitu hukum Indonesia asli golongan rakyat pribumi, yang merupakan hukum yang hidup dalam bentuk tidak tertulis dan mengandung unsur-unsur nasional yang asli yaitu sifat kemasyarakatan dan kekeluargaan, yang berasaskan keseimbangan serta diliputi oleh suasana keagamaan. ${ }^{6}$ Eksistensi hukum adat dapat dilihat melalui implementasi dari hak ulayat.

Hak ulayat merupakan serangkaian wewenang dan kewajiban suatu masyarakat hukum adat yang berhubungan dengan tanah yang terletak dalam lingkungan wilayahnya. ${ }^{7}$ Setiap anggota masyarakat hukum adat berhak dengan bebas mengolah dan memanfaatkan tanah dan sumber daya alam yang ada dalam kawasan tersebut. Orang luar tidak berhak kecuali atas izin dari masyarakat hukum adat. Hak ulayat kesatuan-kesatuan masyarakat hukum adat mendudukkan pada tempat yang sewajarnya dalam negara Indonesia dewasa ini, seperti yang tergambar dalam Pasal 3 UU No. 5 Tahun 1960 tentang Peraturan Dasar Pokok-Pokok Agriaria (UUPA) menentukan bahwa: ${ }^{8}$

Pelaksanaan hak ulayat dan hak-hak yang serupa itu dari masyarakat-masyarakat hukum adat, sepanjang menurut kenyataannya masih ada, harus sedemikian rupa sehingga sesuai dengan kepentingan nasional dan negara, yang berdasarkan persatuan bangsa serta tidak boleh bertentangan dengan undangundang dan peraturan- peraturan yang lebih tinggi.

Memperhatikan isi Pasal 3 UUPA di atas, maka Pasal 3 ini harus dikaitkan dengan Pasal 58 UUPA yang masih mengakui berlakunya hakhak ulayat maupun hak-hak adat lain. Pengakuan hak ulayat dalam UUPA tidak secara deklaratif, karena memiliki beberapa persyaratan yang harus dipenuhi, menurut Pasal 3 UUPA adalah: a) Masih terdapat dalam masyarakat (masih merupakan kenyataan hidup); b)Sesuai dengan kepentingan nasional/negara; c) Tidak bertentangan dengan undang-undang dan peraturan lain. ${ }^{9}$ Pengakuan hak ulayat dengan persyaratan seperti di atas perlu dipertanyakan tentang makna ketentuan tersebut. Menurut Bahar, ketentuan ini mempunyai

\footnotetext{
Hilman Hadikusuma, 2014, Pengantar Ilmu Hukum Adat Indonesia, Edisi Revisi, Mandar Maju, Bandung, hlm. 34.

M. Djojodiguno, 1964, Asas-asas Hukum Adat, Yayasan Badan Penerbit Gadjah Mada, Yogyakarta, hlm. 7.

Boedi Harsono, 2003, Hukum Agraria Indonesia, Sejarah Pembentukan UUPA, Isi dan Pelaksanaannya, Jilid I, Cetakan Kesembilan, (Edisi Revisi), Djambatan, Jakarta, hlm. 174

Ibid., hlm. 179.

Winahyu Erwiningsih, 2009, Hak Menguasai Negara Atas Tanah, Total Media, Yogyakarta hlm. 4 dan lihat juga Pasal 3 Undang-Undang Nomor 5 Tahun 1960 tentang Peraturan Dasar Pokok-Pokok Agraria (Lembaran Negara Republik Indonesia Tahun 1960 Nomor 104, Tambahan Lembaran Negara Republik Indonesia Nomor 2043).

Ibid., hlm. 5.
} 
kelemahan yaitu kelemahan logika dan kelemahan politik.

Dari segi logika tidak mungkin suatu masyarakat hukum adat yang dibangun berdasarkan hubungan genealogis dan teritorial bisa menjadi tidak ada kecuali kalau musnah karena bencana alam yang sangat dahsyat atau terjadinya genocide. Jika hal seperti itu terjadi maka negara berkewajiban melindungi agar masyarakatnya tidak musnah. Dari segi politik pernyataan "sesuai dengan kepentingan nasional dan negara, yang berdasarkan atas persatuan bangsa" merupakan suatu a priori yang mengandung kecurigaan dari pemerintah terhadap masyarakat hukum adat. Pernyataan ini menunjukkan seolah-olah masyarakat hukum adat itu bukan merupakan bagian kenasionalan, kenegaraan dan kebangsaan. Bukankah pemenuhan kepentingan masyarakat hukum adat itu merupakan bagian upaya pemenuhan kepentingan nasional?. ${ }^{10}$

Lebih jauh terkait persyaratan "tidak boleh bertentangan dengan peraturan yang lebih tinggi” sebagaimana disebutkan di atas secara konstitusional juga mengakui secara bersyarat keberadaan hakhak tradisional komunitas di Indonesia yaitu dalam Pasal 18B ayat (2) Undang-Undang Dasar Negara Kesatuan Republik Indonesia 1945 (UUD NRI Tahun 1945) menyatakan bahwa negara mengakui dan menghormati kesatuan-kesatuan masyarakat hukum adat beserta hak-hak tradisionalnya sepanjang masih hidup dan sesuai dengan perkembangan masyarakat dan prinsip Negara Kesatuan Republik Indonesia, yang diatur dalam undang-undang. Setelah UUD NRI Tahun 1945 mengadopsi empat pesyaratan bagi masyarakat hukum adat, kemudian berbagai undang-undang yang lahir pasca amandemen mengikuti alur tersebut, antara lain oleh UndangUndang No. 7 Tahun 2004 tentang Sumber Daya Air yang saat ini diputuskan tidak berlaku lagi oleh Mahkamah Konstitusi sehingga untuk mengisi kekosongan hukum diberlakukan Undang-Undang No. 11 Tahun 1974 tentang Pengairan dan Undang-
Undang No. 39 Tahun 2014 tentang Perkebunan.

Pengakuan bersyarat ini mengindikasikan bahwa negara masih belum bersungguh-sungguh membuat ketentuan yang jelas untuk menghormati dan mengakui hak ulayat masyarakat hukum adat. Pengaturan tentang masyarakat hukum adat dan hak ulayatnya sampai hari ini masih bersifat tidak jelas dan tidak tegas. Tidak jelas karena belum ada aturan yang konkrit tentang hak-hak yang terkait dengan keberadaan masyarakat adat yang dapat dinikmatinya. Sebagaimana yang terjadi dengan Masyarakat Hukum Adat Moronene Hukaea Laea yang berdiam di Taman Nasional Rawa Aopa saat ini. Perjalanan panjang dalam upaya untuk memperoleh pengakuan dan perlindungan atas keberadaannya secara formal baru didapatkan di tahun 2015 melalui Peraturan Daerah Kabupaten Bombana Nomor 4 Tahun 2015 tentang Pengakuan, Perlindungan dan Pemberdayaan Masyarakat Adat Moronene Hukaea Laea.

Peraturan daerah tersebut dalam implementasinya yang berkenaan dengan wilayah adat masih belum definitif karena perlu "berkoordinasi" dan menunggu persetujuan/ penetapan dari pihak Taman Nasional. Hal ini dikarenakan wilayah adat berada dalam wilayah Taman Nasional. Keadaan ini secara otomatis memiliki konsekuensi terhadap pelaksanaan hak ulayat dalam wilayah adat dari Masyarakat Hukum Adat Moronene Hukaea Laea. Masyarakat Hukum Adat Moronene Hukaea Laeamendiami wilayah ulayatnya sebelum Indonesia merdeka. Pasca kemerdekaan, wilayahnya ditetapkan sebagai lokasi Taman Nasional Rawa Aopa Watumohai. Penetapan ini mengusik warga karena mulai dilarang atau dibatasi untuk mengembangkan hasil pertaniannya dalam bercocok tanam. Akibatnya warga terus berjuang untuk mendapatkan hak ulayatnya. ${ }^{11}$

Hak ulayat dalam hal ini juga memiliki unsur-unsur minimal yang harus dipunyai oleh sesuatu yang disebut hak. Secara umum unsur-

\footnotetext{
10 S. Bahar, 2005, Inventarisasi dan Perlindungan Hak Masyarakat Hukum Adat, Komisi Nasional Hak Asasi Manusia, Jakarta, hlm. 8.

11 Sulawesi Institute, "Menanti Implementasi Perda Pengakuan, Perlindungan dan Pemberdayaan Masyarakat Adat Moronene Hukaea Laea di Kabupaten Bombana", Policy Brief, Vol. I, No. 1, 2015, hlm. 3.
} 
unsur yang membangun adanya suatu hak ada 3 (tiga) yaitu subyek hak, obyek hak dan adanya kewenangan dari subyek hak terhadap obyek yang dilindungi oleh hukum. ${ }^{12}$ Jika Masyarakat Hukum Adat Moronene Hukaea Laea di Taman Nasional Rawa Aopa mendapat pengakuan atas keberadaan sebagai masyarakat hukum adat tapi tidak dengan wilayah adatnya hal ini menyisakan permasalahan implementasi dari hak ulayat yang dimiliki oleh masyarakat tersebut.

Berdasarkan uraian di atas maka yang menjadi permasalahan adalah pertama, bagaimanakah konsep pengaturan mengenai hubungan hak ulayat masyarakat hukum adat dengan hak menguasai negara?; kedua, bagaimanakah implementasi hubungan hak ulayat Masyarakat Adat Moronene Hukaea Laea dengan hak menguasai negara di Taman Nasional Rawa Aopa Watumohai?

\section{B. Metode Penelitian}

Penelitian ini merupakan studi kasus (case$s t u d y)^{13}$ tentang implementasi hubungan hak ulayat dengan hak menguasai negara di Taman Nasional Rawa Aopa Sulawesi Tenggara, khususnya terkait dengan sumber daya alam masyarakat adat Moronene Hukaea Laea. Sebagai penelitian hukum pendekatan yang digunakan tergolong penelitian hukum empiris (socio-legal research) karena berfokus pada penerapan dari aturan-aturan hukum, dan pada sisi lain fokus kajiannya meliputi proses, cara, perbuatan mengatur. ${ }^{14}$

Lahirnya pendekatan penelitian hukum empiris (socio-legal research) merupakan konsekuensi dari ilmu hukum yang memang bersifat terbuka sehingga inetraksi antara ilmu hukum dengan ilmu-ilmu lainnya, terutama ilmu sosial merupakan suatu keniscayaan. ${ }^{15} \mathrm{Di}$ samping itu, cara atau metode penelitian tidaklah bersifat kaku karena suatu cara atau metode hanyalah alat (tool) untuk mencapai tujuan. Bergantung pada obyek (formal) ilmu pengetahuan, tujuan penelitian dan tipe data yang akan diperoleh sehingga ia sepenuhnya tergantung pada logika dan konsistensi peneliti. ${ }^{16}$

Penelitian ini dilakukan pada komunitas Masyarakat Hukum Adat Moronene Hukaea Laea berdasarkan pertimbangan bahwa masyarakat hukum adat ini berdiam di Taman Nasional Rawa Aopa Watumohai Kabupaten Bombana Provinsi Sulawesi Tenggara.Data diperoleh melalui penelitian kepustakaan dan penelitian lapangan. Data yang diperoleh langsung di lapangan disebut data primer atau data dasar (primary data atau basic data) dan data yang diperoleh dari bahan pustaka dinamakan data sekunder (secondary data). ${ }^{17}$

Penelitian Kepustakaan dilakukan untuk memperoleh data sekunder yaitu data yang sudah dalam bentuk jadi, seperti data dalam dokumen dan publikasi yang meliputibahan hukum primer, sekunder, dan tersier. Bahan hukum primeryaitu bahan-bahan hukum yang mengikat berupa peraturan perundang-undangan, antara lain yaitu: a) Undang-Undang Dasar Negara Republik Indonesia 1945; b) Undang-Undang No. 5 Tahun 1960 tentang Peraturan Dasar Pokok-Pokok Agraria; c) Undang-Undang No. 11 Tahun 1974 tentang Pengairan; d)Undang-Undang No. 41 Tahun 1999 tentang Kehutanan; e) Undang-Undang No. 39 Tahun 2014 tentang Perkebunan; f)Putusan Mahkamah Konstitusi Nomor 35/PUU-X/2012; dan g)Peraturan Daerah Kabupaten Bombana No. 4 Tahun 2015 tentang Pengakuan, Perlindungan dan Pemberdayaan Masyarakat Adat Moronene Hukaea Laea.

\footnotetext{
12 Alon Harel, 2005, "Theories of Right”, dalam M.P Golding dan W. A. Edmundson (Ed.), Philosophy of Law and Legal Theory, Blackwell Publishing Ltd, hlm. 91-106.

13 Soerjono Soekanto, 2008, Pengantar Penelitian Hukum, UI-Press, Jakarta, hlm. 15-17.

14 Balai Pustaka, 1990, Kamus Besar Bahasa Indonesia, Tim Penyusun Kamus Besar Bahasa Indonesia. Departemen Pendidikan dan Kebudayaan, Pusat Pembinaan dan Pengembangan Bahasa, Jakarta, hlm. 56.

5 S. Wignjosoebroto, 2002, Hukum: Paradigma, metode dan dinamika masalahnya, ELSAM dan HuMa, Jakarta, hlm. 121.

16 Maria. S. W. Soemardjono, 1996, Pedoman Pembuatan Usulan Penelitian, Sebuah Panduan Dasar, Gramedia Pustaka Utama, Jakarta, hlm. 10 .

17 Soerjono Soekanto, Op.cit., hlm. 11-12.
} 
Bahan Hukum Sekunder yaitu bahan hukum yang memberi penjelasan bahan primer yang terdiri atas buku-buku tentang konsep hak menguasai negara, hak ulayat, hubungan antara hukum negara dan hukum adat. Hasil-hasil penelitian berupa makalah, artikel yang mempunyai keterkaitan dengan permasalahn yang diteliti. Bahan Hukum Tersier yaitu bahan hukum yang memberi petunjuk atau penjelasan bahan hukum primer dan sekunder seperti kamus hukum, kamus besar bahasa Indonesia dan ensiklopedia. Penelitian lapangan dilakukan untuk memperoleh data primer dengan meneliti/ observasi ke lokasi penelitian dan melakukan wawancara dengan menggunakan pedoman wawancara secara terstruktur dan tidak terstruktur atau menggunakan kombinasi keduanya yang sudah dipersiapkan sebelumnya untuk mendapatkan keterangan yang lebih terperinci dan jelas.

Subyek penelitian ini terdiri dari Reponden yaitu mereka yang mengetahui atau memiliki informasi mengenai materi penelitian karena mengalami secara langsung yakni Masyarakat Hukum Adat Moronene Hukaea Laea yang diwakili Ketua adat, Kepala Balai Taman Nasional Rawa Aopa Watumohai, Sulawesi Institute lembaga swadaya masyarakat yang mendampingi Masyarakat Hukum Adat Moronene Hukaea Laea dan Narasumber yaitu pihak yang mengetahui atau memiliki informasi mengenai materi penelitian karena profesi dan keahliannya, dalam hal ini adalah Dosen Universitas Halu Oleo Fakultas Ilmu Budaya Program Studi Antropologi, Sarlan Adi Jaya, S.Sos., M.Si. Data yang diperoleh dari penelitian disusun dan dikelompokkan secara sistematis sesuai dengan permasalahan yang diteliti, untuk diolah dan dianalisis secara kualitatif. Data disajikan secara deskriptif sehingga diperoleh deskripsi tentang implementasi hubungan hak ulayat masyarakat hukum adat dengan hak menguasai negara di Taman Nasional Rawa Aopa Watumohai Kabupaten Bombana Provinsi Sulawesi Tenggara.

\section{Hasil Penelitian dan Pembahasan \\ 1. Konsep Hubungan Hak Ulayat dengan Hak Menguasai Negara}

Hak ulayat sebagai kewenangan sekaligus kewajiban mempunyai kekuatan berlaku ke dalam dan ke luar. Ke dalam berhubungan dengan para warganya, sedang kekuatan berlaku ke luar dalam hubungannya dengan bukan anggota masyarakat hukum adatnya yang disebut "orang asing" atau "orang luar". ${ }^{18}$ Hak ulayat mengandung 2 (dua) unsur yaitu unsur kepunyaan yang termasuk bidang hukum perdata dan unsur tugas-kewenangan untuk mengatur penguasaan dan memimpin penggunaan tanah bersama yang termasuk bidang hukum publik. Unsur tugas-kewenangan yang termasuk bidang hukum publik tersebut pelaksanaannya dilimpahkan kepada kepala adat sendiri atau bersama-sama dengan para tetua adat masyarakat hukum adat yang bersangkutan. ${ }^{19}$ Masyarakat hukum adat merupakan penjelmaan dari seluruh anggotanya yang mempunyai hak ulayat.

Konsep dasar hak menguasai oleh negara di Indonesia dimuat dalam Pasal 33 ayat (3) UUD 1945 yang berbunyi: Bumi dan air dan kekayaan alam yang terkandung di dalamnya dikuasai oleh negara dan dipergunakan untuk sebesar-besar kemakmuran rakyat. ${ }^{20}$ Penjelasan otentik tentang pengertian bumi, air dan kekayaan alam yang terkandung di dalamnya (disebut sumber daya alarn selanjutnya disingkat SDA) dikuasai oleh negara, termuat dalam UUPA mulai berlaku pada tanggal 24 September 1960. Pasal 2 UUPA yang merupakan aturan pelaksanaan Pasal 33 ayat (3) UUD, menjelaskan pengertian hak menguasai SDA oleh negara.

Sesuai dengan Penjelasan Umum II/2 UUPA, perkataan "dikuasai" dalam Pasal ini bukanlah berarti "dimiliki", akan tetapi adalah pengertian yang memberi wewenang kepada negara, sebagai organisasi kekuasaan dari bangsa Indonesia itu,

\footnotetext{
Budi Harsono, Op.cit., hlm. 180.

Ibid., hlm. 250.

Pasal 33 ayat (3) Undang-Undang Dasar Negara Republik Indonesia Tahun 1945.
} 
untuk pada tingkatan yang tertinggi: ${ }^{21}$

a. mengatur dan menyelenggarakan peruntukan, penggunaan, persediaan dan pemeliharaannya;

b. menentukan dan mengatur hak-hak yang dapat dipunyai atas (bagian dari) bumi, air dan ruang angkasa itu;

c. menentukan dan mengatur hubunganhubungan hukum antara orang- orang dan perbuatan-perbuatan hukum yang mengenai bumi, air dan ruartg angkasa;

d. segala sesuatu dengan tujuan untuk mencapai sebesar-besar kemakmuran rakyat dalam rangka masyarakat yang adil dan makmur.

Menelaah konsep pengaturan $\mathrm{di}$ atas, terdapat 2 (dua) hal utama yang saling berhubungan satu sama lain yaitu hak menguasai negara dan penguasaan tersebut ditujukan untuk menciptakan kemakmuran/kesejahteraan bagi rakyat. Hal ini diperkuat dengan Pasal 34 UUD 1945 yang secara keseluruhan mengatur mengenai kewajiban negara untuk memberikan kesejahteraan bagi rakyat yang berupa pemeliharaan bagi fakir miskin dan anak terlantar, pengembangan sistem jaminan sosial serta penyediaan fasilitas kesehatan dan fasilitas umum yang layak.

Hubungan hukum antara negara dengan sumber daya alamnya melahirkan hak menguasai sumber daya alam oleh negara. Hubungan antara masyarakat hukum adat dengan sumber daya alam di lingkungan wilayah adatnya melahirkan hak ulayat. Idealnya hubungan hak menguasai oleh negara dan hak ulayat terjalin secara harmonis dan seimbang. Artinya, kedua hak itu sama kedudukan dan kekuatannya dan tidak saling merugikan namun peraturan perundang-undangan di Indonesia yang memberikan pengakuan bersyarat atas keberadaan masyarakat hukum adat beserta hak-haknya sebagaimana diatur dalam Undang-Undang No.
41 Tahun 1999 tentang Kehutanan Pasal 67 ayat (1) bahwa masyarakat hukum adat sepanjang kenyataannya masih ada dan diakui keberadaannya, berhak:

a) Melakukan pemungutan hasil hutan untuk pemenuhan kebutuhan sehari-hari masyarakat adat yang bersangkutan;

b) Melakukan kegiatan pengelolaan hutan berdasarkan hukum adat yang berlaku dan tidak bertentangan dengan undang-undang;

c) Mendapatkan pemberdayaan dalam rangka meningkatkan kesejahteraannya.

Fakta empiris di lapangan juga menunjukkan bahwa keberadaan masyarakat hukum adat dan hak-hak tradisionalnya justru turut serta menjaga dan melindungi hutan. Secara umum bisa terlihat beberapa prinsip-prinsip kearifan lokal yang masih dihormati dan dipraktikkan oleh kelompok kelompok masyarakat hukum adat, yaitu antara lain: ${ }^{22}$

1. Masih hidup selaras alam dengan mentaati mekanisme ekosistem di mana manusia merupakan bagian dariekosistem yang harus dijaga keseimbangannya;

2. Adanya hak penguasaan dan/atau kepemilikan bersama komunitas (communal tenure/"property" rights) atas suatu kawasan hutan adat masih bersifat eksklusif sehingga mengikat semua warga untuk menjaga dan mengamankannya dari kerusakan;

3. Adanya sistem pengetahuan dan struktur kelembagaan (pemerintahan) adat yang memberikan kemampuan bagi komunitas untuk memecahkan secarabersama masalah-masalah yang

\footnotetext{
${ }_{21}$ Marchel R. Maramis, "Kajian Atas Perlinungan Hukum Hak Ulayat Dalam Perspektif Hak Asasi Manusia”, Jurnal Hukum UNSRAT, Vol. 21, No. 4, 2013, hlm. 100.

22 Abdon Nababan, "Pengelolaan Hutan Berbasis Masyarakat Adat: Antara Konsep dan Realitas", Makalah, Seminar Hutan Tanaman Rakyat, Untuk Apa dan Siapa, Pertemuan Mitra Siemenpuu Foundation, Muara Jambi, 5 November 2008, hlm. 4.
} 
mereka hadapi dalam pemanfaatan sumberdaya hutan;

4. Ada sistem pembagian kerja dan penegakan hukum adat untuk mengamankan sumberdaya milik bersama dari penggunaan berlebihan baik oleh masyarakat sendiri maupun oleh orang luar;

5. Ada mekanisme pemerataan distribusi hasil "panen" sumberdaya alam milik bersama yang bisa meredam kecemburuan sosial di tengah masyarakat.

Hal-hal yang disebutkan di atas tidak serta merta berlaku bagi masyarakat hukum adat yang telah mendapatkan pengakuan tentang keberadaannya. Khususnya masyarakat hukum adat yang wilayah adatnya berada dalam kawasan tertentu masih membutuhkan penetapan. Hal ini berpotensi mengakibatkan adanya dominasi hak menguasai oleh negara terhadap hak ulayat. Konsepsi penguasaan negara mendapatkan legitimasinya dengan berpijak pada teori kekuasaan negara yang dinyatakan Van Vollenhoven bahwa negara sebuah organisasi tertinggi dari bangsa yang diberi kekuasaan untuk mengatur segala-galanya dan negara berdasarkan kedudukannya memiliki kewenangan untuk peraturan hukum. ${ }^{23}$

UUPA berpangkal pada pengakuan hak ulayat tetapi membatasi pelaksanaannya. Misalnya jika negara c.q. pemerintah akan memberikan sesuatu hak atas tanah (sumber daya alam) di wilayah hak ulayat masyarakat hukum adat maka sebagai tanda pengakuan itu masyarakat hukum adat yang bersangkutan sebelumnya akan didengar pendapatnya dan akan diberi recognitie yang memang ia berhak menerimanya sebagai pemegang hak ulayat. Recognitie tidak ada kaitannya dengan pelepasan hak milik melainkan suatu tanda pengakuan yang sebagian tanahnya dipergunakan oleh pemerintah guna menyelenggarakan kepentingan umum warga masyarakat. ${ }^{24}$

Pasal 28 ayat (1) UUPA menguraikan bahwa yang dapat diberikan hak guna usaha ialah tanahtanah yang dikuasai langsung oleh negara. Tanahtanah demikian itu disebut tanah negara. Termasuk dalam hal pemberian recognitie tersebut di atas tanah yang diberikan dengan hak guna usaha masih ada hak ulayatnya. Tanah-tanah yang masih ada hak ulayatnyapun menurut pengertian UUPA termasuk golongan "tanah negara" termasuk golongan tanah yang "dikuasai langsung oleh negara".

Rikardo Simarmata menguraikan bahwa persyaratan terhadap masyarakat hukum adat dan hak ulayatnya yang dilakukan oleh UUD 1945 pasca amandemen memiliki sejarah yang dapat dirunut dari masa kolonial. ${ }^{25}$ Algemene Bepalingen (AB) 1848, Regering Reglement (RR) 1854, dan $l S$ (1920 dan 1929) mengatakan bahwa orang pribumi dan timur asing yang tidak mau tunduk kepada hukum Perdata Eropa, diberlakukan undang-undang agama, lembaga dan adat kebiasaan masyarakat, sepanjang tidak bertentangan dengan asas-asas yang diakui umum tentang keadilan. ${ }^{26}$ Persyaratan yang demikian berifat diskriminatif karena terkait erat dengan eksistensi kebudayaan.

Pengakuan bersyarat terhadap masyarakat hukum adat dalam sejarah Republik Indonesia dimulai pada UUPA, undang-undang kehutanan lama, undang-undang pengairan, undang-undang kehutanan baru dan beberapa peraturan departemen dan lembaga pemerintahan. Dalam UndangUndang Dasar Tahun 1945 sebelum amandemen mengakui masyarakat hukum adat secara deklaratif tanpa persyaratan. Setelah Undang-Undang Dasar Negara Kesatuan Republik Indonesia 1945 mengadopsi persyaratan bagi masyarakat hukum adat, kemudian berbagai undang-undang yang lahir pasca amandemen mengikuti alur tersebut, antara lain oleh Undang- undang No. 7 Tahun 2004

\footnotetext{
23 Notonagoro, 1984, Politik Hukum dan Pembangunan Agraria, Bina Aksara, Jakarta, hlm. 99.

24 Maria Rita Roewiastuti, "Reforma Agraria dan Masyarakat Adat", http://binadesa.org/reforma-agraria-dan-masyarakat-adat/, diakses 1 Mei 2016.

Rikardo Simarmata, 2006, Pengakuan Hukum terhadap Masyarakat Adat di Indonesia, UNDP, Jakarta, hlm. 309-310.

26 Ibid.
} 
tentang Sumber Daya Air dan Undang-Undang No. 39 Tahun 2014 tentang Perkebunan.

Pengakuan bersyarat ini mengindikasikan bahwa pemerintah masih belum bersungguhsungguh membuat ketentuan yang jelas untuk menghormati dan mengakui hak ulayat masyarakat hukum adat. Pengaturan tentang masyarakat hukum adat dan hak ulayatnya sampai hari ini masih tidak jelas dan tidak tegas. Tidak jelas karena belum ada aturan yang konkrit tentang hak-hak yang terkait dengan keberadaan masyarakat yang dapat dinikmatinya, dan dikatakan tidak tegas karena belum adanya mekanisme penegakan hukum yang dapat ditempuh dalam pemenuhan hak masyarakat hukum adat melalui jalur pengadilan.

Persyaratan dalam Pasal 18B ayat (2) UUD

NRI tahun 1945 berserta dengan serangkaian persyaratan yang dilanjutkan oleh beberapa undang-undang sumberdaya alam menunjukkan bahwa negara cq. pemerintah baru mengakui dan menghormati hak ulayat masyarakat hukum adat secara terbatas, belum sampai pada tindakan hukum untuk melindungi dan memenuhi agar hak ulayat masyarakat hukum adat dapat terpenuhi. Bahkan sama sekali belum meyentuh mekanisme penegakan hukum nasional bila terjadi pelanggaran terhadap hak ulayat yang sudah dianggap sebagai hak asasi manusia.

Pengakuan terhadap masyarakat hukum adat sudah pada lingkup internasional. Konferensi PBB tentang Lingkungan Hidup dan Pembangunan yang diadakan di Rio de Janeiro pada Juni 1992, menghasilkan sebuah perkembangan baru bagi masyarakat hukum adat tentang hubungan masyarakat hukum dengan PBB. Konferensi tersebut mengakui bahwa masyarakat hukum adat dan komunitasnya memiliki peran yang sangat penting dalam pengelolaan lingkungan dan pembangunan, berdasarkan ilmu yang dimiliki dan praktik-praktik tradisional.

Usaha dalam lingkup nasional dan internasional untuk menerapkan pembangunan yang berkesinambungan dan berorientasi lingkungan harus mengakui, mengakomodasi, memajukan dan memperkuat peran masyarakat hukum adat dan komunitasnya. Pasal 26 dari Agenda 21 (program aksi yang ditetapkan dalam konferensi) diperuntukkan bagi masyarakat hukum adat. Masyarakat hukum adat mengadakan pertemuan dalam Pertemuan Bumi, yaitu suatu forum organisasi non pemerintah yang terbesar. Forum tersebut menetapkan Deklarasi Kari-Oka, sebuah deklarasi mengenai lingkungan dan pembangunan. Salah satu hasil dari forum tersebut adalah ditandatanganinya Konvensi Keanekaragaman Hayati yang memasukkan kondisi-kondisi yang berhubungan dengan masyarakat adat. ${ }^{27}$

Pada 29 Juni 2006 disepakati Deklarasi PBB tentang Hak-Hak Masyarakat Asli (United Nations Declaration on the Rights of Indigenous Peoples). Deklarasi ini bersifat progresif karena mengakui landasan-landasan penting dalam perlindungan, pengakuan dan pemenuhan hakhak masyarakat hukum adat. Deklarasi ini berisi pengakuan baik terhadap hak individu maupun hak kolektif masyarakat hukum adat, hak atas identitas budaya, hak atas pendidikan, kesehatan, bahasa dan hak-hak dasar lainnya. Deklarasi ini mengakui hak masyarakat hukum adat untuk menentukan nasib sendiri (self--determination), dan pengakuan terhadap hak masyarakat hukum adat atas tanah, wilayah dan sumberdaya alam dan partisipasi dalam pembangunan.

Kebutuhan masyarakat hukum adat untuk mendapatkan pengakuan negara substansinya adalah agar mendapatkan perlindungan dan jaminan pelaksanaan hak-hak masyarakat hukum adat. Pluralisme hukumI Indonesia meski secara konseptual termasuk kategori lemah (weak legal pluralism) namun dirasakan dapat memberikan keadilan bagi masyarakat hukum adat. Teori keadilan distributive oleh John Rawls menetapkan kebebasan sebagai prinsip pertama dari keadilannya berupa, "Prinsip Kebebasan yang Sama". ${ }^{28}$ Prinsip

\footnotetext{
27 Boedi Harsono, Op.cit., hlm. 235.

28 Andre Ata Ujan, 2001, Keadilan Dan Demokrasi; Telaah Filsafat Politik John Rawls, Kanisius, Yogyakarta, hlm. 86.
} 
ini berbunyi "Setiap orang harus mempunyai hak yang sama atas sistem kebebasan dasar yang sama yang paling luas sesuai dengan sistem kebebasan serupa bagi semua". Semua kebebasan dasar tersebut harus dijamin keberlakuannya secara konstitusional. ${ }^{29}$

Sehubungan dengan tuntutan pengakuan dan perlindungan terhadap hak ulayat masyarakat hukum adat yang seringkali dimarjinalkan dalam kehidupan bernegara, sesuatu yang dianggap mendesak untuk dilakukan adalah menyusun Rancangan Undang-Undang Pengakuan dan Perlindungan Hak Masyarakat Hukum Adat (RUU PPHMHA). Saat ini Dewan Perwakilan Rakyat Republik Indonesia (DPR RI) sedang menyiapkan RUU tersebut dan telah dibahas dalam paripurna DPR RI.

Dalam rangka penyusunan RUU PPHMHA tersebut diharapkan memberi makna positif bagi upaya perwujudan kesejahteraan rakyat. Diterbitkannya Undang-Undang tentang Pengakuan dan Perlindungan HakMasyarakat Hukum Adat, memberikan dorongan kuat kepada pemerintah untuk mengaturpengakuan, penghormatan dan perlindungan terhadap kesatuan masyarakat hukum adat beserta hak-hak tradisionalnya. Pemerintah hendaknya merespon dan mengakomodasi prinsip-prinsip dan nilai-nilai yang terdapat dalam masyarakat hukum adat, yangsenyatanya sudah dijalankan secara turun temurun oleh masyarakat hukum adat.

\section{Implementasi Hubungan Hak Ulayat dengan Hak Menguasai Negara di Taman Nasional Rawa Aopa Watumohai}

Saat ini di Taman Nasional Rawa Aopa Watumohai berdiam masyarakat hukum adat yang dikenal dengan sebutan Masyarakat Hukum Adat Moronene Huake Laea. Sebagaimana umumnya komunitas masyarakat adat yang tersebar di seluruh penjuru Nusantara, Masyarakat Hukum Adat Moronene Hukaea Laea merupakan masyarakat pribumi/asli etnis Moronene yang hidup dan berkembang berdasarkan asal usul leluhur secara turun temurun di atas suatu wilayah dan memiliki kedaulatan atas tanah dan sumber daya alam lainnya. Kehidupan sosial budayanya diatur oleh hukum adat dan lembaga hukum adat yang mengelola keberlangsungan kehidupan masyarakatnya selama ini.

Tobu adalah wilayah terkecil dari suatu wilayah kerajaan Moronene dahulu kala yang dihuni sekitar 50 kepala keluarga. Hukaea sendiri berasal dari dua suku kata, Huka artinya Pohon Melinjau dan Ea artinya Besar jadi Hukaea berarti Pohon Melinjau besar. Laea, La artinya Sungai dan Ea artinya Besar jadi Laea berarti Sungai besar. Penamaan tempat kedua Tobu tersebut menandakan bahwa di Tobu Hukaea terdapat rerimbunan pohon Melinjau yang besar, sementara Laea menandakan bahwa di Tobu tersebut terdapat sungai yang besar. Saat ini di kedua Tobu tersebut dihuni sebanyak 110 kepala keluarga. ${ }^{30}$

Sejarah Keberadaan Tobu Hukaea dan Tobu Laeamenurut Antropolog dari Universitas Halu Oleo, Sarlan Adi Jaya, S.Sos., M.Si telah diakui sejak zaman kerajaan Moronene, Hukaea dan Laea adalah wilayah otonom dari kerajaan Moronene yang masing-masing Tobu dikepalai oleh seorang yang berpangkat puutobu. Wilayah Hukaea dan Laea telah tercatat di dalam peta administrasi kerajaan Moronene yang dibuat oleh Belanda. Kedua Tobu ini sekarang secara administratif berada di Kecamatan Lantari Jaya Kabupaten Bombana, Propinsi Sulawesi Tenggara. ${ }^{31}$ Masyarakat hukum adat Moronene Hukaea Laea secara turun temurun menetapkan wilayah adatnya dengan batas-batas alam. Penetapan tersebut dimaksudkan agar seluruh anggota komunitas adatnya tidak melakukan pengelolaan sumber daya alam di luar batas alam

\footnotetext{
Ibid.

30 Naskah Akademik Rancangan Peraturan Daerah Kabupaten Bombana tentang Pengakuan, Perlindungan dan Pemberdayaan Masyarakat Adat Moronene Hukaea Laea di Kabupaten Bombana, 2015, hlm. 3.

31 Hasil Wawancara dengan Sarlan Adi Jaya, Dosen Antropologi Fakulatas Ilmu Sosial dan Ilmu Politik Universitas Haluoleo Sulawesi Tenggara, 10 Februari 2016.
} 
yang telah ditetapkan. Wilayah masyarakat hukum adat tersebut kemudian dibagi menjadi 8 (delapan) wilayah kelola adat, yakni: ${ }^{32}$

1. Inalahi Pue (Hutan Inti)

2. Inalahi Popali dan Kotoria (Hutan Penyangga)

3. Inalahi Peuma (Hutan Perkebunan)

4. Olobu (Hutan Kecil)

5. Kura (Perladangan)

6. Tana Lueno (Padang Savana)

7. Bako (Hutan Bakau)

8. Bolo (Tambak Ikan Tradisional)

Penetapan wilayah kelola adat tersebut ditetapkan berdasarkan kearifan lokal masyarakat hukum adat Moronene Hukaea Laea dalam mengelola sumber daya alamnya.Upaya untuk mempertahankan eksistensi masyarakat hukum adat Moronene Hukaea Laea telah melalui berbagai rintangan akibat adanya gangguan dari luar komunitasnya. Di masa perang gerilya, dilakukan oleh pasukan DI/TII pada tahun 1953. Setelah Indonesia merdeka, di era pemerintahan orde baru masyarakat hukum adat Morenene Hukaea Laea harus berhadapan dengan negara.

Bermula pada tanggal 17 Desember 1990 Pemerintah Republik Indonesia melalui Menteri Kehutanan menetapkan secara sepihak wilayah adat masyarakat adat Moronene Hukaea Laea sebagai kawasan konservasi melalui Surat Keputusan Menteri Kehutanan RI No. 756/Kpts II/1990 tentang Penetapan Kelompok Hutan Rawa Aopa Watumohai sebagai kawasan hutan dengan fungsi sebagai Taman Nasional. Penetapan secara sepihak itu disertai dengan upaya pemerintah mengusir masyarakat hukum adat Moronene Hukaea Laea dari wilayah hukum adatnya melalui operasi telik sandi sapu jagad yang berlangsung sejak tahun 1997, 1999, 2000, dan berakhir pada tahun 2002. ${ }^{33}$

Putusan Mahkamah Konstitusi Nomor 35/ PUU-X/2012 atau selanjutnya disebut Putusan MK 35 dianggap sebagai putusan yang memberi angin segar dan kepastian hukum atas ruang hidup masyarakat adat yang selama ini terkungkung oleh UU No. 41 Tahun 1999 tentang Kehutanan. Perubahan substansial yang dimaksud setelah adanya putusan MK 35 terdapat pada Pasal 1 angka 6 Undang-Undang No. 41 Tahun 1999 yang sebelumnya mengatur bahwa hutan adat adalah hutan negara yang berada dalam wilayah masyarakat hukum adatberubah menjadi hutan adat adalah hutan yang berada dalam wilayah masyarakat hukum adat.

Putusan MK Nomor 35 Tahun 2012 tampaknya telah mengeliminasi kekuasaan negara terhadap hutan adat akan tetapi pengakuan wilayah adat bagi masyarakat adat yang berada dalam kawasan hutan masih menjadi kewenangan pemerintah. Proses pengakuan ini diatur dengan Peraturan Bersama Menteri Dalam Negeri, Menteri Kehutanan, Menteri Pekerjaan Umum dan Kepala Badan Pertanahan Nasional No. 79/PRT/M/2014 Nomor 8/SKB/X/2014 tentang Tata Cara Penyelesaian Penguasaan Tanah yang berada dalam Kawasan Hutan bahwa pengakuan hak masyarakat hukum adat sepanjang kenyataannya masih ada. Teknis pengakuan atas wilayah adat yang berada dalam kawasan hutan didahului dengan proses verifikasi oleh tim yang dibentuk secara bersamasama antara pemerintah daerah dengan instansi vertikal Kementerian Kehutanan dan Lingkungan Hidup yang ada di daerah.

Konsep pengaturan ini memiliki kerancuan pemahaman terkait urgensi dilakukannya verifikasi tentang keberadaan masyarakat hukum adat yang dalam hal ini telah memiliki dasar hukum pengakuan keberadaannya melalui instrumen Peraturan Daerah, diketahui bahwa proses penyusunan Perda juga melalui penelitian. Artinya, pengakuan keberadaan masyarakat hukum adat terpisah dengan pengakuan hak masyarakat hukum adat dalam wilayah hukum adatnya. Padahal hak ulayat sebagai sebuah hak seharusnya memiliki unsur-unsur yang membangunnya yaitu subyek hak, obyek hak dan kewenangan dari subyek hak atas obyek hak yang

\footnotetext{
Hasil Wawancara dengan Mansur Labamba, Ketua Adat Masyarakat Hukum Adat Moronene Hukaea Laea, 7 Februari 2016.

33 Sulawesi Institute, Loc.cit.
} 
dilindungi hukum secara utuh sebagai kesatuan yang menyeluruh, tidak terpisah-pisah.

Fransisco Moga sebagai Kepala Balai Taman Nasional menjelaskan, saat ini wilayah desa Hukaea masih masuk kawasan zona Rimba. Suatu kawasan yang dilarang melakukan adanya aktifitas kegiatan masyarakat melakukan kegiatan pertanian. Segera setelah hadirnya Perda itu, Pemkab Bombana melaporkan ke Kementerian lingkungan Hidup sebab wilayah tersebutberada di Taman Nasioanal sehingga secara hirarki, Balai Taman Nasional Rawa Aopa Watumohai melaporkan pada Kementerian terkait, sebagai langkah solusi tentunya harus ada perubahan zonasi (dari zonasi hutan Rimba menjadi Zonasi Hutan tradisional). ${ }^{34}$

Berdasarkan keadaan ini masyarakat hukum adat Moronene Hukaea Laea yang secara dasar hukum telah mendapatkan pengakuan atas keberadaan mereka sebagai masyarakat hukum adat melalui Peraturan Daerah Kabupaten Bombana No. 4 Tahun 2015 namun belum secara otomatis mendapatkan haknya atas wilayah adat termasuk hak pengelolaan dan pemanfaatan sumber daya alam. Pelaksanaan hak ulayatnya masih dibatasi oleh peraturan yang berlaku bagi sebuah Taman Nasional. Pengakuan keberadaan masyarakat hukum adat dalam hal ini tidak berimplikasi pada pengakuan kewenangan atas wilayah dan hak untuk mengelola atau memanfaatkan sumber daya alamnya.

Masyarakat hukum adat yang telah mendapatkan pengakuan tentang keberadaannya tidak dapat langsung dapat menggunakan haknya. Khususnya masyarakat hukum adat yang wilayah adatnya berada dalam kawasan tertentu masih membutuhkan penetapan. Peraturan Menteri Agraria dan Tata Ruang/Kepala Badan Pertanahan Nasional No. 9 Tahun 2015 tentang tata cara penetapan hak komunal tanah masyarakat hukum adat dan masyarakat yang berada di dalam kawasan tertentu. Peraturan ini memperkenalkan istilah baru yaitu hak komunal yang merupakan hak milik bersama atas tanah suatu masyarakat hukum adat atau hak milik bersama atas tanah yang diberikan kepada masyarakat yang berada dalam kawasan hutan atau perkebunan.

Keberadaan hak ulayat adalah berdasarkan adanya masyarakat hukum adat dan salah satu kriteria dalam membuktikan keberadaan masyarakat hukum adat sebagaimana disebutkan dalam Penjelasan Pasal 67 ayat (1) Undang-undang No. 41 Tahun 1999 tentang Kehutanan adalah adanya wilayah hukum adat yang jelas. Persoalannya dalam implementasi terkait dengan pelaksanaan hak ulayat masih belum tegas. Bagi masyarakat hukum adat Moronene Hukaea Laea yang telah mendapatkan pengakuan atas keberadaannya namun untuk dapat menggunakan hak ulayat dalam wilayah adat yang masih belum definitif karena masih harus menunggu penetapan dari pihak Taman Nasional adalah sebuah persoalan serius. Terlebih jangka waktu untuk penetapan itu tidak ditentukan.

Menurut Mansur Labamba yang merupakan ketua adat dari masyarakat hukum adat Moronene Hukaea Laea bahwa bagi masyarakat hukum adat tidak masalah jika dalam wilayah adatnya sebagian termasuk dalam wilayah Taman Nasional, namun yang diinginkan adalah sebuah pengakuan atas hal tersebut. ${ }^{35}$ Masyarakat hukum adat Moronene Hukaea Laea keberatan jika karena permasalahan sebagian wilayah adat yang terkait dengan Taman Nasional sehingga pengakuan atas wilayah adatnya menjadi tertunda. Eksistensi atas hak ulayat masyarakat hukum adat juga tergantung atas pengakuan wilayah adat tersebut, termasuk didalamnya keseluruhan eksistensi dari hukum adatnya yang dikenal dengan nama Adati Tongano Wonua. Usaha untuk mendapatkan pengakuan dan penghormatan atas keberadaan masyarakat hukum adat ini adalah demi keberlangsungan masyarakat hukum adat Moronene Hukaea Laea.

\section{Kesimpulan}

Berdasarkan uraian pada bagian sebelumnya

\footnotetext{
34 Wawancara dengan Fransisco Moga, Kepala Balai Taman Nasional Rawa Aopa Watumohai, 14 November 2015.

35 Hasil Wawancara dengan Mansur Labamba, Ketua Adat Masyarakat Hukum Adat Moronene Hukaea Laea, 7 Februari 2016.
} 
dapat disimpulkan bahwa, Pertama, konsep pengaturan mengenai hubungan hak ulayat masyarakat hukum adat dengan hak menguasai negaratertuang dalam Pasal 33 ayat (3) UUD NRI 1945 selanjutnya di atur dalam UUPA Pasal 2 menjelaskan pengertian hak menguasai SDA oleh negara. Khusus yang berkaitan langsung dengan implementasi hak ulayat dari masyarakat hukum adat, negara memberikan pengakuan dengan syarat-syarat tertentu dan prosedur hukum tertentu yang jika dikaji lebih jauh menyisakan beberapa persoalan.

Salah satunya adalah pengakuan atas keberadaan suatu masyarakat hukum adat tidak serta merta memberikan pengakuan atas hak ulayat dalam wilayah hukum adatnya terlebih atas pengelolaan dan pemanfaatan sumber daya alam yang berada dalam kawasan hutan tertentu karena pengakuan wilayah adat bagi masyarakat hukum adat masih menjadi kewenangan pemerintah. Proses pengakuan ini diatur dengan Peraturan Bersama Menteri Dalam Negeri, Menteri Kehutanan, Menteri Pekerjaan Umum dan Kepala Badan Pertanahan Nasional No. 79/PRT/M/2014 Nomor
8/SKB/X/2014 tentang Tata Cara Penyelesaian Penguasaan Tanah yang berada dalam Kawasan Hutan bahwa pengakuan hak masyarakat hukum adat sepanjang kenyataannya masih ada.

Kedua, implementasi hubungan hak ulayat masyarakat hukum adat dengan hak menguasai negara di Taman Nasional Rawa Aopa Watumohai Kabupaten Bombana, Propinsi Sulawesi Tenggara adalah ditandai dengan masyarakat hukum adat memperoleh pengakuannya melalui Peraturan Daerah Kabupaten Bombana Nomor 4 Tahun 2015 tentang Pengakuan, Perlindungan dan Pemberdayaan Masyarakat Adat Moronene Hukaea Laea namun untuk penetapan atas wilayah adat masih harus menunggu penetapan pihak Taman Nasionalhal initerkait dengan pemerintah pusat sebagai pelaksana wewenang/kekuasaan dari negara. Keadaan ini tidak memungkinkan bagi masyarakat hukum adat untuk menggunakan hak ulayatnya dengan utuh sehingga tujuan pelaksanaan dari prinsip pengakuan dan perlindungan masyarakat hukum adat yakni peningkatan kualitas hidup dan kemakmuran masyarakat tidak akan terpenuhi.

\section{DAFTAR PUSTAKA}

\section{A. Buku}

Bahar, S., 2005, Inventarisasi dan Perlindungan Hak Masyarakat Hukum Adat, Komisi Nasional Hak Asasi Manusia, Jakarta.

Balai Pustaka, 1990, Kamus Besar Bahasa Indonesia, Tim Penyusun Kamus Besar Bahasa Indonesia. Departemen Pendidikan dan Kebudayaan, Pusat Pembinaan dan Pengembangan Bahasa, Jakarta.

Djojodiguno, M., 1964, Asas-asas Hukum Adat, Yayasan Badan Penerbit Gadjah Mada, Yogyakarta.

Erwiningsih, Winahyu, 2009, Hak Menguasai Negara Atas Tanah, Total Media, Yogyakarta. Hadikusuma, Hilman, 2014, Pengantar Ilmu Hukum Adat Indonesia, Edisi Revisi, Mandar Maju, Bandung.
Harsono, Boedi, 2003, Hukum Agraria Indonesia, Sejarah Pembentukan UUPA, Isi dan Pelaksanaannya, Jilid I, Cetakan Kesembilan, (Edisi Revisi), Djambatan, Jakarta.

Kusumaatmadja, Mochtar, 1976, Hukum, Masyarakat dan Pembinaan Hukum Nasional: Suatu uraian tentang Landasan Pikiran, Pola dan Makanisme Pembaharuan Hukum di Indonesia, Binacipta, Bandung.

Notonagoro, 1984, Politik Hukum danPembangunan Agraria, Bina Aksara, Jakarta.

Simarmata, Rikardo, 2006, Pengakuan Hukum terhadap Masyarakat Adat di Indonesia, UNDP, Jakarta.

Soekanto, Soerjono, 2008, Pengantar Penelitian Hukum, UI-Press, Jakarta.

Soemardjono, Maria. S. W., 1996, Pedoman 
Pembuatan Usulan Penelitian, Sebuah

Panduan Dasar, PT. Gramedia Pustaka Utama, Jakarta.

Ujan, Andre Ata, 2001, Keadilan Dan Demokrasi; Telaah Filsafat Politik John Rawls, Kanisius, Yogyakarta.

Wignjosoebroto, S., 2002, Hukum: Paradigma, metode dan dinamika masalahnya, ELSAM dan HuMa, Jakarta.

\section{B. Artikel Jurnal}

Griffth, J., 1986, "What is Legal Pluralism?", Journal Of Legal Pluralism, No. 24.

Maramis, Marchel R., "Kajian Atas Perlinungan Hukum Hak Ulayat Dalam Perspektif Hak Asasi Manusia", Jurnal Hukum UNSRAT, Vol. 21, No. 4, 2013.

\section{Makalah/Policy Brief}

Nababan, Abdon, "Pengelolaan Hutan Berbasis Masyarakat Adat: Antara Konsep dan Realitas", Makalah, Seminar Hutan Tanaman Rakyat, Untuk Apa dan Siapa, Pertemuan Mitra Siemenpuu Foundation, Muara Jambi, 5 November 2008.

Soemardjono, Maria S.W., "Pluralisme Hukum Di Bidang Pertanahan", Makalah, "Konferensi Internasional tentang Penguasaan Tanah dan Kekayaan Alam di Indonesia yang Sedang Berubah: Mempertanyakan Kembali Berbagai Jawaban", Yayasan Kemala, Jakarta, 11-13 Oktober 2004.

Sulawesi Institute, "Menanti Implementasi Perda Pengakuan, Perlindungan dan Pemberdayaan Masyarakat Adat Moronene Hukaea Laea di Kabupaten Bombana", Policy Brief, Vol. I, No. 1, 2015.

\section{Artikel dalam Antologi dengan Editor}

Harel, Alon, 2005, "Theories of Right", dalam M.P Golding dan W. A. Edmundson (Ed.), Philosophy of Law and Legal Theory, Blackwell Publishing Ltd.

\section{E. Internet}

Maria Rita Roewiastuti, "Reforma Agraria dan Masyarakat Adat", http://binadesa.org/ reforma-agraria-dan-masyarakat-adat/, diakses 1 Mei 2016.

\section{F. Peraturan Perundang-Undangan}

Undang-Undang Dasar Negara Republik Indonesia Tahun 1945.

Undang-Undang Nomor 5 Tahun 1960 tentang Peraturan Dasar Pokok-Pokok Agraria (Lembaran Negara Republik Indonesia Tahun 1960 Nomor 104, Tambahan Lembaran Negara Republik Indonesia Nomor 2043).

\section{G. Dokumen Lain-lain}

Naskah Akademik Rancangan Peraturan Daerah Kabupaten Bombana tentang Pengakuan, Perlindungan dan Pemberdayaan Masyarakat Adat Moronene Hukaea Laea di Kabupaten Bombana, 2015.

Wawancara dengan Fransisco Moga, Kepala Balai Taman Nasional Rawa Aopa Watumohai, 14 November 2015.

Hasil Wawancara dengan Mansur Labamba, Ketua Adat Masyarakat Hukum Adat Moronene Hukaea Laea, 7 Februari 2016.

Hasil Wawancara dengan Sarlan Adi Jaya, Dosen Antropologi Fakulatas Ilmu Sosial dan Ilmu Politik Universitas Haluoleo Sulawesi Tenggara, 10 Februari 2016. 